\title{
Effect of dietary inclusion of guanidinoacetic acid on broiler performance
}

\author{
Efecto de la inclusión dietética del ácido guanidinoacético en el desempeño de pollos de engorde
}

Efeito da inclusão dietética do ácido guanidinoacético no desempenho de frangos de corte

Kamilla M Borges D; Heloisa H de C Mello D; Marcos B Café D; Emmanuel Arnhold D;

Hyara P F Xavier D; Helder F de Oliveira* D; Alessandra G Mascarenhas (D.

Universidade Federal de Goiás, Escola de Veterinária e Zootecnia, Goiânia, Goiás, Brazil.

To cite this article:

Borges KM, Mello HHC, Café MB, Arnhold E, Xavier HPF, Oliveira HF, Mascarenhas AG. Effect of dietary inclusion of guanidinoacetic acid on broiler performance. Rev Colomb Cienc Pecu 2021; 34(2). 95-104. DOI: https://doi.org/10.17533/udea.rccp.v34n2a02

\begin{abstract}
Background: Creatine and its precursor, guanidinoacetic acid (GAA), decrease protein degradation, avoiding amino acid offset to gluconeogenesis. Objective: To evaluate the inclusion of GAA in the pre-initial diet (1 to 7 days) on performance, digestibility, and blood parameters of broilers from one to 21 days of age. Methods: 252 male broiler chickens aged one day were distributed in a completely randomized design with seven replicates and 12 animals per experimental unit. Treatments consisted of a basal diet, and the basal added with 0.10 and $0.20 \%$ GAA. Results: From days 1 to 7 , a tendency on improved feed conversion (FC) was observed for broilers receiving $0.20 \%$ GAA $(\mathrm{p}<0.10)$. Between 7 and 14 days, FC improved, as well as a tendency was observed on improved weight gain in animals fed $0.20 \%$ GAA. Animals that received $0.20 \%$ GAA showed higher blood concentrations of creatine kinase. Blood creatine and blood glucose did not differ between treatments at day six. The assimilation coefficient of crude protein increased during days 3 to 7 for animals receiving 0.20\% GAA. On the period between 17 and 21 days, no difference was observed between treatments. Intestinal weight and length did not show significant differences. Conclusion: Dietary inclusion of $0.20 \%$ GAA during the pre-initial stage could improve weight gain and feed conversion of broilers between 1 and 14 days of age.
\end{abstract}

Keywords: additive; broilers; chicken; creatine; feed additive; guanidinoacetic acid; metabolism; nutrition; organ biometry; poultry.

Received: October 4, 2018; accepted: July 7, 2020

*Corresponding author. Avenida Esperança, s/n, Campus Universitário, Goiânia, GO. 74690-900. Tel.: +5562982728873. Email: helder@zootecnista.com.br 


\section{Resumen}

Antecedentes: La creatina suministra energía y el ácido guanidinoacético (GAA) es su precursor y actúa como sustrato energético, reduciendo la degradación proteica y evitando el desvío de aminoácidos para gluconeogénesis. Objetivo: Evaluar el GAA en la dieta de pre-iniciación (1 a 7 dias) sobre el desempeño, la digestibilidad y los parámetros sanguíneos de pollos entre 1 y 21 dias de edad. Métodos: Se utilizaron 252 pollitos de engorde machos de un día de edad, distribuidos en un diseño completamente al azar, con siete repeticiones y 12 aves por unidad experimental. Los tratamientos consistieron en: ración basal y ración basal adicionada con 0,10 y $0,20 \%$ de GAA. Resultados: En el período de 1 a 7 días se observó una tendencia de mejora de la conversión alimenticia (FC) en las aves que recibieron $0,20 \%$ de GAA (p<0,10). De 7 a 14 días hubo mejoría en FC y tendencia de mejora en ganancia de peso de los animales que recibieron 0,20\% de GAA. Los animales que recibieron $0,20 \%$ de GAA presentaron mayor concentración sanguínea de creatina quinasa. La creatinina y la glucosa sanguínea a los seis días no difirieron entre los tratamientos. El coeficiente de metabolización de la proteína bruta aumentó en el período de 3 a 7 días en los animales que recibieron $0,20 \%$ de GAA. Para el período de 17 a 21 días no hubo diferencia entre los tratamientos. Para peso y longitud del intestino no se presentaron diferencias significativas. Conclusión: El GAA a un nivel de 0,20\% en la dieta preinicial podria mejorar la ganancia de peso, y la conversión alimenticia en el período de 1 a 14 días de edad en pollos de engorde.

Palabras clave: ácido guanidinoacético; aditivo; aditivo alimentario; aves de corral; biometría de órganos; creatina; metabolismo; nutrición; pollos de engorde.

\section{Resumo}

Antecedentes: A creatina é uma substância que fornece energia e o ácido guanidinoacético (GAA) é seu precursor atuando como substrato energético, menor degradação proteica evitando o desvio de aminoácidos para gliconeogênese. Objetivo: Avaliar o GAA em dietas pré-iniciais sobre o desempenho, a digestibilidade e parâmetros sanguíneos. Métodos: Foram utilizados 252 pintos de corte machos de um a 21 dias de idade distribuído sem delineamento inteiramente casualizado, sete repetições e 12 aves por unidade experimental. Os tratamentos consistiram: ração basal e rações com 0,10 e 0,20\% de GAA. Resultados: No período de 1 a 7 dias foi observada tendência de melhora da conversão alimentar $(\mathrm{FC})(\mathrm{p}<0,10)$ quando as aves receberam $0,20 \%$ de GAA. No período de 7 a 14 dias houve melhora na FC e tendência de melhora do ganho de peso dos animais que receberam $0,20 \%$ de GAA. Animais que receberam 0,20\% de GAA apresentaram concentração sanguínea da enzima creatina quinase maior. A creatinina sanguínea aos seis dias e glicose sanguínea não diferiram entre os tratamentos. O coeficiente de metabolização da proteína bruta foi aumentado no período de 3 a 7 dias para animais que receberam $0,20 \%$ de GAA, para o período de 17 a 21 dias não houve diferença entre os tratamentos. Peso e comprimento do intestino não apresentaram diferenças significativas. Conclusão: O GAA em nível de 0,20\% na dieta pré-inicial melhoram o ganho de peso, e a conversão alimentar no período de 1 a 14 dias de idade em frangos.

Palavras-chave: ácido guanidinoacético; aditivo; aditivo alimentar; aves; biometria de órgãos; creatina; frango; metabolismo; nutrição. 


\section{Introduction}

The poultry industry is in constant growth, increasing the production and commercialization of poultry meat and other products every year. Improvement in genetics, animal welfare, environment, handling, nutrition, hygiene, and equipment consolidates broiler production more and more. Artificial incubation makes it possible to produce a high number of chicks in a short period of time. The incubation period corresponds to about $30 \%$ of the cycle of broilers (Gonçalves et al., 2013). The initial phase, from 1 to 7 days after hatching, is of great importance for broiler development. The increased metabolic rate during this stage and the high potential for growth can render embryonic resources insufficient, possibly exhausting during the post-hatch period (Yair et al., 2013). Posthatch fasting can affect organ development and body growth, thus jeopardizing performance, primarily due to decreased protein synthesis (Riccardi et al., 2009). Inversely, feeding during the first hours of life can anticipate intestine development and prevent body proteins from being mobilized for energy production.

Among the additives used in feeds is Creatine (CRE), a substance found in products of animal origin since it is mostly stored in muscle. Feeds of plant origin provide insufficient amounts to cover the minimum CRE requirement. Creatine provides temporary energy and transports it between production and consumption sites. It maintains re-synthesis rates of ATP/ADP and plays an essential role in muscle contraction (Wyss e Kaddurah-Daouk, 2000). It is considered chemically unstable and costly. Thus, guanidinoacetic acid (GAA), a CRE precursor, is often used to replace CRE because it is cheaper and more stable (Dilger et al., 2013). Dietary inclusion of GAA helps to save essential amino acids, allowing their use for protein synthesis.

The objective of this study was to evaluate the effects of dietary inclusion of GAA on broiler digestibility, performance and blood parameters.

\section{Materials and Methods}

\section{Ethical considerations}

The study was approved by the Ethics Committee on Animal Use of Universidade Federal de Goiás (UFG; protocol no 011/16).

\section{Location and animals}

The experiment was conducted at UFG, Goiás, Brazil. A total of 252 one--day old male chicks (Cobb lineage) were used, distributed in a completely randomized design with 3 treatments, 7 replicates, and 12 chickens per replicate (21 experimental units).

Chickens were placed in five floors of steel battery cages $(0.77 \times 0.74 \times 0.23 \mathrm{~m})$, equipped with drinkers, gutter feeders and metal trays to collect excreta. Batteries were kept inside barns, and ventilation was controlled with curtains. Maximum and minimum temperatures were recorded twice a day by thermometers distributed throughout the barn. Incandescent lamps were used to provide luminosity and heating support. Temperatures recorded during the experiment in the periods from 1 to 7,8 to 14 , and 15 to 21 days were, respectively: 24.4 and 33.7; 21.8 and 32.1; 21.5 and $31.8^{\circ} \mathrm{C}$.

Feed and water were provided ad libitum during the experimental period. Treatments consisted of a basal diet without GAA, and basal with 0.10 or $0.20 \%$ GAA. The animals received the dietary treatment until 7 days of age, and the basal diet without GAA until they were 21 days old. The corn-soybean based feed was formulated to meet the minimum nutrient requirements throughout the experimental period, according to Rostagno et al. (2011) (Table 1).

Weighing of animals and feed was conducted on days $1,7,14$, and 21 to calculate performance variables. On day 6, two animals per experimental unit were randomly chosen for blood and intestinal sampling. Chickens were fasted for 2 hours and subsequently dulled in a $\mathrm{CO}_{2}$ gas chamber. 
Table 1. Centesimal composition of experimental diets containing different levels of guanidinoacetic acid (GAA).

\begin{tabular}{|c|c|c|c|c|}
\hline \multirow{3}{*}{ Ingredients (\%) } & \multicolumn{4}{|c|}{ Treatments } \\
\hline & \multicolumn{3}{|c|}{1 to 7 days(\% GAA) } & \multirow{2}{*}{$\begin{array}{c}8 \text { to } 21 \text { days(No } \\
\text { GAA) } \\
- \\
\end{array}$} \\
\hline & $\mathbf{0}$ & 0.100 & 0.200 & \\
\hline Corn & 54.866 & 54.866 & 54.866 & 59.242 \\
\hline Soybean & 38.144 & 38.144 & 38.144 & 34.638 \\
\hline Guanidinoacetic acid & 0.000 & 0.100 & 0.200 & - \\
\hline Starch & 0.200 & 0.100 & 0.000 & 0.000 \\
\hline Soybean oil & 2.169 & 2.169 & 2.169 & 2.136 \\
\hline Dicalcium phosphate & 1.909 & 1.909 & 1.909 & 1.509 \\
\hline Chalk & 0.913 & 0.913 & 0.913 & 0.923 \\
\hline Common salt & 0.507 & 0.507 & 0.507 & 0.481 \\
\hline L-Lysine HCL & 0.412 & 0.412 & 0.412 & 0.313 \\
\hline DL-Methionine & 0.361 & 0.361 & 0.361 & 0.288 \\
\hline L-Threonine & 0.115 & 0.115 & 0.115 & 0.065 \\
\hline Premix $^{1}$ & 0.400 & 0.400 & 0.400 & 0.400 \\
\hline TOTAL & 100.000 & 100.000 & 100.000 & 100.000 \\
\hline \multicolumn{5}{|l|}{ Calculated composition } \\
\hline $\begin{array}{l}\text { Metabolizable energy } \\
(\mathrm{kcal} / \mathrm{kg})\end{array}$ & 2.950 & 2.950 & 2.950 & 3.000 \\
\hline Sodium (\%) & 0.220 & 0.220 & 0.220 & 0.210 \\
\hline Calcium (\%) & 0.920 & 0.920 & 0.920 & 0.819 \\
\hline $\begin{array}{l}\text { Available phosphorus } \\
(\%)\end{array}$ & 0.470 & 0.470 & 0.470 & 0.391 \\
\hline Crude protein (\%) & 22.20 & 22.20 & 22.20 & 20.80 \\
\hline Lysine Dig. (\%) & 1.310 & 1.310 & 1.310 & 1.174 \\
\hline Met. + Cist. Dig. (\%) & 0.944 & 0.944 & 0.944 & 0.846 \\
\hline Threonine Dig. (\%) & 0.852 & 0.852 & 0.852 & 0.763 \\
\hline
\end{tabular}

'Composition per kg of product: vit. A 12,000,000 IU; vit. D3 2,200,000 IU; vit. E 30,000 IU; vit. B1 2,200 mg; vit B2 6,000 mg; vit. B6 3,300 mg; panthothenic acid 13,000 mg; biotin $110 \mathrm{mg}$; vit. K3 2,500 mg; folic acid 1,000 mg; nicotinic acid 53,000 mg; niacin 25,000 mg; vit. B12 16,000 $\mu \mathrm{g}$; selenium $0.25 \mathrm{~g}$; antioxidant 120,000 mg, and Enough quantity to (QSP) vehicle $1.000 \mathrm{~g}$; manganese 75,000 mg; iron 20,000 mg; zinc 50,000 mg; copper 4,000 mg; cobalt $200 \mathrm{mg}$; iodine 1,500 mg, and QSP vehicle $1.000 \mathrm{~g}$.

Blood sampling was performed by femoral vein puncture and $2 \mathrm{~mL}$ blood was stored in vacutainer tubes with sodium fluoride as anticoagulant and kept in Styrofoam boxes filled with ice. At the UFG's Departamento de Patología Clínica, tubes without anticoagulant were kept resting for 2 hours, then centrifuged and the resulting serum was used to determine creatinine and creatinine-kinase levels. Tubes containing anticoagulant went through the same centrifugation process, with plasma collected to determine blood glucose levels. Determinations were carried out using specific commercial kits in an automated biochemical analyser (CM 200, Wiener Lab Group $\left.{ }^{\circledR}\right)$. Sampled intestines were weighted, and their lengths measured with a measuring tape.

Two metabolism assays were conducted: one from the 3 rd to the 7 th day and the other from the 17 th to the 21 st day of age. The nutrient assimilation coefficient in feeds was determined from total excreta, following Sakomura and Rostagno (2007) methods. Excreta were collected 
and kept frozen until further analysis. At the end of the sampling period, excreta were thawed, homogenized, and $400 \mathrm{~g}$ of sample were dried in a forced-air oven at $\pm 55^{\circ} \mathrm{C}$ for 72 hours. Then, samples were weighed and ground in a Willey mill for analysis. The analysis was carried out in the Laboratório de Nutrição Animal at UFG. Dry matter, crude protein, and ether extract from excreta and feed samples were determined according to the methods described by Silva and Queiroz (2009).

\section{Statistical analysis}

Data were analysed using the $\mathrm{R}$ software. An ANOVA was performed, and averages were compared using the Tukey test. Adopting $\alpha=0.05$, and considering a tendency when $\alpha$ was between 0.05 and 0.10 .

\section{Results}

\section{Performance}

Supplementing GAA in broiler feed during the pre-initial period from 1 to 7 days did not affect weight gain and food consumption
( $>>0.05)$ (Table 2). However, we observed a tendency of improvement for feed conversion $(p<0.08)$ in animals that were fed $0.20 \%$ GAA compared to the other treatments.

From 1 to 14 days, animals that received the diet containing $0.20 \%$ GAA until 7 days of age showed a better feed conversion at 14 days $(p<0.05)$ compared to animals that received the remaining treatments. The $0.20 \%$ GAA broiler chickens also showed a tendency $(\mathrm{p}<0.07)$ of a greater weight gain in this same period, which explains the improved feed conversion results. Regarding the use of GAA in experimental feeds at the pre-initial period, no residual effect was verified $(\mathrm{p}>0.05)$ on broiler performance until 21 days of age.

Creatinine, creatine kinase (CK), and blood glucose

The concentration of $\mathrm{CK}$ in the blood of animals that received $0.20 \%$ GAA was significantly higher $(\mathrm{p}<0.01)$ when compared to those that received other treatments (Table 3).

Table 2. Effects of dietary inclusion of guanidinoacetic acid (GAA) during the first 7 days of age on broiler performance from 1 to 7, 1 to 14 , and 1 to 21 days of age.

\begin{tabular}{|c|c|c|c|c|c|c|}
\hline \multirow{2}{*}{ Variable } & \multicolumn{3}{|c|}{ GAA $(\%)$} & \multirow{2}{*}{ p-value } & \multirow{2}{*}{ CV (\%) } & \multirow{2}{*}{$\begin{array}{c}\text { Standard } \\
\text { error }\end{array}$} \\
\hline & 0.00 & 0.10 & 0.20 & & & \\
\hline \multicolumn{7}{|c|}{1 to 7 days } \\
\hline WG (kg) & 0.165 & 0.168 & 0.172 & 0.3586 & 5.9 & \pm 0.003 \\
\hline FI (kg) & 0.131 & 0.137 & 0.131 & 0.4524 & 7.6 & \pm 0.003 \\
\hline $\mathrm{FCR}(\mathrm{kg} / \mathrm{kg})$ & 0.798 & 0.820 & 0.761 & 0.0718 & 5.6 & \pm 0.017 \\
\hline \multicolumn{7}{|c|}{1 to 14 days } \\
\hline WG (kg) & 0.421 & 0.441 & 0.452 & 0.0638 & 5.3 & \pm 0.008 \\
\hline FI (kg) & 0.490 & 0.513 & 0.506 & 0.3232 & 5.5 & \pm 0.010 \\
\hline $\mathrm{FCR}(\mathrm{kg} / \mathrm{kg})$ & $1.164 \mathrm{a}$ & $1.161 \mathrm{a}$ & $1.120 \mathrm{~b}$ & 0.0138 & 2.4 & \pm 0.010 \\
\hline \multicolumn{7}{|c|}{1 to 21 days } \\
\hline WG (kg) & 0.925 & 0.909 & 0.912 & 0.5224 & 2.9 & \pm 0.010 \\
\hline FI (kg) & 1.160 & 1.169 & 1.150 & 0.7153 & 3.6 & \pm 0.015 \\
\hline FCR $(\mathrm{kg} / \mathrm{kg})$ & 1.286 & 1.286 & 1.266 & 0.4406 & 2.4 & \pm 0.012 \\
\hline
\end{tabular}

$\mathrm{WG}=$ weight gain; FI = Feed Intake; FCR = Feed Conversion Rate; CV = coefficient of variation; (a, b) averages with different letters within the same row differ from each other through the Tukey test $(\mathrm{p}<0.05)$. 
Table 3. Serum parameters in broilers on the sixth day of age receiving different levels of guanidinoacetic acid (GAA).

\begin{tabular}{|c|c|c|c|c|c|c|}
\hline \multirow{2}{*}{ Variable } & \multicolumn{3}{|c|}{ GAA $(\%)$} & \multirow{2}{*}{ p-value } & \multirow{2}{*}{ CV (\%) } & \multirow{2}{*}{$\begin{array}{c}\text { Standard } \\
\text { error }\end{array}$} \\
\hline & 0.00 & 0.10 & 0.20 & & & \\
\hline CK (IU/L) & $167.85 b$ & $112.85 b$ & $247.43 a$ & $<0.001$ & 46.0 & \pm 2.167 \\
\hline $\begin{array}{l}\text { Creatinine } \\
(\mathrm{mg} / \mathrm{dL})\end{array}$ & 0.250 & 0.264 & 0.282 & 0.5509 & 29.6 & \pm 0.021 \\
\hline $\begin{array}{c}\text { Glucose } \\
\text { plasma (mg/ } \\
\text { dL) }\end{array}$ & 245.68 & 255.68 & 255.58 & 0.5032 & 10.2 & \pm 6.876 \\
\hline
\end{tabular}

$\mathrm{CK}=$ creatine kinase $\mathrm{CV}=$ coefficient of variation; $(\mathrm{a}, \mathrm{b})$ averages with different letters within the same row differ from each other through the Tukey test $(\mathrm{p}<0.05)$.

Blood creatinine values at six days of age presented no difference $(\mathrm{p}>0.05)$ between animals that received treatments with GAA inclusion. Blood glucose concentration also did not show any differences $(\mathrm{p}>0.05)$ between treatments.

\section{Nutrient assimilation}

The dry matter (DMAC), crude protein (CPAC), and ether extract (EEAC) assimilation coefficients in the periods ranging from 3 to 7 and 17 to 21 days are shown in table 4 . In the period from 3 to 7 days, no difference was observed $(p>0.05)$ forboth DMAC and EEAC. Asignificant difference was found for CPAC ( $\mathrm{P}=0.0306$ ), which was higher when animals received $0.20 \%$ GAA but did not differ when compared to the group that received $0.10 \%$ GAA. No difference $(p>0.05)$ was found between treatments for the period from 17 to 21 days of age. Providing feeds with GAA inclusion during the pre-initial period did not influence the assimilation coefficient in the period from 17 to 21 days.

\section{Intestine weight and length}

No difference was found between treatments for intestine weight and length ( $p>0.05$; table 5 ).

Table 4. Assimilation coefficients (\%) of dry matter (DMAC), crude protein (CPAC), and ether extract (EEAC) of feeds with different levels of guanidinoacetic acid (GAA) for broiler chickens.

\begin{tabular}{ccccccc}
\hline \multirow{2}{*}{ Variable (\%) } & \multicolumn{7}{c}{ GAA (\%) } & p-value & CV (\%) & Standard error \\
\cline { 2 - 4 } & $\mathbf{0 . 0 0}$ & $\mathbf{0 . 1 0}$ & $\mathbf{0 . 2 0}$ & & & \\
& & & $\mathbf{3}$ to $\mathbf{7}$ days & & \\
DMAC & 68.629 & 68.603 & 68.097 & 0.8451 & 2.8 & \pm 0.727 \\
CPAC & $56.177 \mathrm{~b}$ & $59.561 \mathrm{ab}$ & $60.797 \mathrm{a}$ & 0.0306 & 5.2 & \pm 1.159 \\
EEAC & 86.280 & 85.092 & 85.092 & 0.2385 & 2.0 & \pm 0.666 \\
& & & $\mathbf{1 7}$ to 21 days & & & \\
DMAC & 68.008 & 68.847 & 68.152 & 0.4964 & 2.0 & \pm 0.525 \\
CPAC & 49.454 & 50.502 & 51.879 & 0.1842 & 4.6 & \pm 0.891 \\
EEAC & 84.301 & 83.919 & 83.585 & 0.5120 & 1.3 & \pm 0.430 \\
\hline
\end{tabular}

$\mathrm{CV}=$ coefficient of variation; $(\mathrm{a}, \mathrm{b})$ averages with different letters within the same row differ from each other through the Tukey test $(\mathrm{p}<0.05)$. 
Table 5. Intestine weight and length in broiler chickens receiving feeds with different levels of guanidinoacetic acid (GAA) from 1 to 7 days of age.

\begin{tabular}{|c|c|c|c|c|c|c|}
\hline \multirow{2}{*}{ Variable } & \multicolumn{3}{|c|}{ GAA (\%) } & \multirow{2}{*}{ p-value } & \multirow{2}{*}{ CV $(\%)$} & \multirow{2}{*}{$\begin{array}{c}\text { Standard } \\
\text { error }\end{array}$} \\
\hline & 0.00 & 0.10 & 0.20 & & & \\
\hline Total I.W. (cm) & 16.167 & 16.426 & 16.000 & 0.885 & 13.8 & \pm 0.6081 \\
\hline S.I.L. (cm) & 81.071 & 84.000 & 80.538 & 0.2075 & 6.2 & \pm 1.4225 \\
\hline L.I.L. (cm) & 11.214 & 10.454 & 10.750 & 0.2335 & 10.1 & \pm 0.3151 \\
\hline Total I.L. (cm) & 92.285 & 94.750 & 91.692 & 0.4077 & 6.4 & \pm 1.6536 \\
\hline
\end{tabular}

Total I.W. $=$ Total intestine weight; Total I.L. $=$ Total intestine length; S.I.L. $=$ Small intestine length; L.I.L. $=$ Large intestine length; $\mathrm{CV}=$ coefficient of variation.

\section{Discussion}

\section{Performance}

We included GAA in broiler chicken diets to improve performance during the first days of life. GAA produces creatine without consuming essential amino acids in the process, which can then be used by the organism to perform other functions, such as protein synthesis and to increase muscle mass. Thus, $0.20 \%$ GAA inclusion showed potential for improvement of poultry performance in the period from 1 to 7 days and had a positive effect on feed conversion from 1 to 14 days.

The first seven days of life are determinant for the optimum development of broilers. Therefore, good results should be pursued during this period, as losses are not recovered with compensatory growth until the end of the cycle. This fact can explain the improvement in feed conversion in animals that received a diet containing GAA during the first 7 days of life, which was reflected in the period from 1 to 14 days. In a study by Bryant-Angeloni (2010), the inclusion of GAA in arginine-deficient diets yielded no improvement on weight gain but had the opposite effect on feed conversion. On the other hand, when GAA was added to diets containing adequate arginine concentration, improvement was observed in both weight gain and feed conversion. These results confirm that dietary inclusion of GAA can reduce arginine use, thus improving animal performance. This was also observed by Lemme et al. (2007), who included GAA in male broiler diet between 1 and 41 days of age and found improved feed conversion as well as increased creatine, phosphocreatine, and muscle ATP content. Therefore, energy availability likely increased, affecting the metabolic use of nutrients for growth. Thus, efficient stocking makes energy available in the short term to other metabolic pathways, such as protein synthesis. The improvement in feed conversion can be a reflection of these effects.

Inclusion of $0.20 \%$ GAA in broiler preinitial diets proved efficient for improving feed conversion until 14 days of age. Furthermore, performance improvement can be linked to the fact that GAA inclusion saves amino acids for endogenous synthesis of CRE so they can be used for protein synthesis and muscle growth instead. Additionally, GAA inclusion makes CRE levels increase, as GAA is a direct precursor of CRE, and the energy available for metabolic processes and performance improvement consequently increases.

Supplementing diets with GAA brings better results during the final rearing period of broilers. Michiels et al. (2012) reported that GAA supplementation was beneficial in the final period 
when growth rates are the highest, showcasing the stage when there is better gain:feed relationship. Thus, satisfactory results can be obtained when GAA is supplemented during the final period, considering that greater muscle growth occurs at that stage and more ATP is needed.

In the present study, no residual effect of performance improvement at 21 days was observed. However, the time between birth and adaptation to the experiment was short, in such a way that broilers did not go through a considerable fasting period. Our results suggest that late adaptation, in which the time for chick arrival to the farm enables a longer fast, the response to GAA could be more favorable, which would help to save gluconeogenic precursors.

\section{Creatinine, creatine kinase (CK) and blood glucose}

A higher concentration of $\mathrm{CK}$ could represent more intense muscle growth (Lorsheitter et al., 2015). Thus, higher $\mathrm{CK}$ at the sixth day of life for broilers receiving $0.20 \%$ GAA could explain the tendency for improvement in feed conversion from 1 to 7 days, confirming that higher CK blood concentration can be related to more intense muscle growth in this phase.

Creatinine is a product of creatine (CRE) breakdown from muscles. Consequently, blood creatinine levels are closely related to muscle CRE concentration. Creatinine is filtered in the kidneys and excreted in urine; kidney malfunction compromises creatinine filtration decreasing creatinine excretion and increasing its blood concentration. According to Barbosa et al. (2011), CRE is excreted through the kidneys before being converted into creatinine. This metabolite exists at low concentrations in poultry serum, usually lower than the minimum level detected by laboratory tests. Normal creatinine levels in poultry are constant, between 0.1 and $0.4 \mathrm{mg} / \mathrm{dL}$ (Saukas, 1993). Thus, the creatinine levels observed in the present study are considered normal.

To determine muscle activity, Lemme et al. (2007) established CRE, creatinine, and guanidinoacetic acid directly from the breast muscle in broilers that received GAA from 1 to 41 days of age. At 41 days of age, muscle CRE content increased about 14\% when GAA supplement was raised up to $0.06 \%$ in the diet, suggesting that dietary GAA is a strong source of CRE. Furthermore, the number of high-energy molecules increased with GAA supplementation 1-hour post-mortem, suggesting a more efficient energy stocking due to GAA inclusion, which is available in the short term to metabolic functions such as protein synthesis.

Glucose blood concentration in healthy chickens varies from 200 to $500 \mathrm{mg} / \mathrm{dL}$. Chickens that undergo short fast periods keep normal glucose levels through hepatic gluconeogenesis. In longer periods, however, healthy chickens up to 8 days of age do not reduce glucose use as mammals do (Schmidt et al., 2007). In the present study, blood glucose levels were kept in normal levels for healthy chickens.

\section{Nutrient assimilation}

The crude protein assimilation coefficient (CPAC), which increased in animals that received $0.20 \%$ GAA in the feed during the period between days 3 and 7 , demonstrates an improvement in feed protein usage, reflecting on performance, as can be seen in Table 2. This is noticed when observing feed conversion alone from days 1 to 7 , and feed conversion and weight gain from days 1 to 14 immediately afterward. The improvement in CPAC increased amino acid availability, caused by GAA inclusion, which might have favored the use of the amino acids from protein deposition, thus demonstrating higher muscle growth, which is also justified by higher blood concentration of CK. Muscle growth is related to the improved tendency of weight gain and feed conversion observed during the pre-initial period when $0.20 \%$ GAA was offered.

\section{Intestine weight and length}

According to Viola et al. (2008), increase in intestinal mass and length is related to increased villi size and crypt depth. Some ingredients used in broiler diets can have trophic and 
enterocyte-stimulating effects causing an increase in intestinal mass and improvement of nutrient-absorbing capacity. In the present study, GAA inclusion apparently did not alter intestinal morphology. The GAA did not show activities that stimulate intestinal mass growth during the pre-initial rearing period.

Studying the effects of GAA inclusion is necessary, mostly because GAA methylation to $\mathrm{CRE}$ consumes many methyl groups from methionine. According to Michiels et al. (2012), dietary GAA supplementation increases the demand for methylation. In methylation reactions, homocysteine is produced (Deminice et al., 2009). The great demand for methylation during CRE production causes an accumulation of homocysteine in the blood, as well as a deficiency of methionine, choline, betaine, folic acid, and vitamin B12, increasing the need of these nutrients in the diet. High plasma concentration of homocysteine can cause damage to cell functioning, besides being related to cardiovascular disease (Setoue et al., 2008).

In conclusion, inclusion of $0.20 \%$ GAA in preinitial diets of broiler chickens could improve weight gain and feed conversion between 1 and 14 days of age.

\section{Declarations}

\section{Funding}

This study was financed in part by the Coordenação de Aperfeiçoamento de Pessoal de Nível Superior - Brasil (CAPES) - Finance Code 001.

\section{Conflicts of interest}

The authors declare they have no conflicts of interest with regard to the work presented in this report.

\section{Author contributions}

Kamilla M Borges, Alessandra G Mascarenhas and Heloisa $\mathrm{H}$ de $\mathrm{C}$ Mello: conceived and designed the experiments. Kamilla M Borges and Hyara P F Xavier: performed the experiments.
Emmanuel Arnhold: analyzed the data. Alessandra G Mascarenhas, Heloisa $\mathrm{H}$ de $\mathrm{C}$ Mello and Marcos B Café: contributed reagents, materials, and analytical tools. Kamilla M Borges and Helder F de Oliveira: wrote the paper. Helder F de Oliveira: edited the manuscript.

\section{References}

Barbosa TS, MoriCK, PolônioLB,PonsanoEHG, Ciarlini PC. Perfil bioquímico sérico de galinhas poedeiras na região de Araçatuba, SP. Semina: Ciênc Agrár 2011; 32(4):1583-1588. DOI: https://dx.doi.org/10.5433/1679-0359.2011v32n4p1583

Bryant-Angeloni KI. Dietary guanidino acetic acid spares arginine and dietary 1-homoserine spares threonine in the chick. [Master of Animal Science] 2010; 1-57. University of Illinois, Illinois, USA.

Deminice R, Portari GV, Vannucchi H, Jordao AA. Effects of creatine supplementation on homocysteine levels and lipid peroxidation in rats. Br J Nutr 2009; 102(1):110-116. DOI: https://doi.org/10.1017/S0007114508162985

DilgerRN,Bryant-AngeloniK,PayneRL,Lemme A, Parsons CM. Dietary guanidino acetic acid is an efficacious replacement for arginine for young chicks. Poult Sci 2013; 92(1):171-177. DOI: https://doi.org/10.3382/ps.2012-02425

Gonçalves FM, Santos VL, Contreira CL, Farina G, Kreuz BS, Gentilini FP, Anciuti MA, Rutz F. Nutrição in ovo: estratégia para nutrição de precisão em sistemas de produção avícola. Arch Zootec 2013; 62 Suppl:45-55. DOI: https://doi.org/10.21071/az.v62i237.1956

Lemme A, Ringel J, Sterk A, Young JF. Supplemental guanidinoacetic acid affect energy metabolism of broilers. 16 th European Symposium on Poultry Nutrition; 2007, Strasbourg, França. World Poultry Science Association. [access nov 2, 2016]. URL: http://www.cabi.org/Uploads/ animal-science/worlds-poultry-scienceassociation/WPSA-france-2007/29.pdf 
Lorsheitter LM, Ferreira TZ, Valle SF, Vieira SL, Bergmann GP, Kindlein L. Comportamento da atividade da creatina quinase em frangos de corte com White striping de diferentes idades e submetidas a dietas distintas. $42^{\circ}$ Congresso Bras. de Medicina Veterinária e $1^{\circ}$ Congresso Sul-Brasileiro da ANCLIVEPA; 2015; Curitiba, Brasil. [access jan 15, 2017]. URL: http://www. infoteca.inf.br/conbravet/smarty/templates/ arquivos template/upload arquivos/acervo/628.pdf

Michiels J, Maertens L, Buyse J, Lemme A, Rademacher M, Dierick NA, De Smet S. Supplementation of guanidinoacetic acid to broiler diets: Effects on performance, carcass characteristics, meat quality, and energy metabolism.PoultSci2012;91(2):402-412.DOI: https://doi.org/10.3382/ps.2011-01585

Riccardi RR, Malheiros EB, Boleli IC. Efeito do jejum pós-eclosão sobre pintos de corte provenientes de ovos leves e pesados. Ciênc AnimBras 2009; 10(4):1013-1020.DOI: https:// www.revistas.ufg.br/vet/article/view/1194

Rostagno HS, Albino LFT, Donzele JL, Gomes PC, Oliveira RF, Lopes DC, Ferreira AS, Barreto SLT, Euclides RF. Tabelas brasileiras para aves e suínos: composição de alimentos e exigências nutricionais. Viçosa, Minas Gerais (BR): Editora da Universidade Federal de Viçosa; 2011.

Sakomura NK, Rostagno HS. Métodos de pesquisa em nutrição de monogástricos. Jaboticabal, São Paulo (BR): FUNEP; 2007.

Saukas TN. Variáveis hematológicas e bioquímicas em aves (Gallus gallus, LINNAEUS, 1758) inoculadas com amostras vacinal e de campo do vírus da doença infecciosa bursal. [Doctoral Thesis] 1993. Faculdade de
Medicina Veterinária e Zootecnia. Universidade Estadual Paulista, São Paulo, Brasil.

Schmidt EMS, Locatelli-Dittrich R, Santin E, Paulillo AC. Patologia clínica em aves de produção - Uma ferramenta para monitorar a sanidade avícola - Revisão. Arch Vet Sci 2007; 12(3):9-20. DOI: http://dx.doi.org/10.5380/avs.v12i3.10906

Setoue M, Ohuchi S, Morita T, Sugiyama K. Hyperhomocysteinemia induced by guanidinoacetic acid is effectively suppressed by choline and betaine in rats. Biosci Biotechnol Biochem 2008; 72(7):1696-1703. DOI: https://doi.org/10.1271/bbb.70791

Silva JD, Queiroz AC. Análise de alimentos métodos químicos e biológicos. $3^{\mathrm{a}}$ ed. Viçosa, Minas Gerais (BR): Editora da Universidade Federal de Viçosa; 2009.

Viola ES, Vieira SL, Torres CA, Freitas DM, Berres J. Desempenho de frangos de corte sob suplementação com ácidos lático, fórmico, acético e fosfórico no alimento ou na água. R Bras Zootec 2008; 37(2):296-302. DOI: https://doi.org/10.1590/S1516-35982008000200016

Wyss M, Kaddurah-Daouk R. Creatine and creatinine metabolism. Physiol Rev 2000; 80(3):1107-1213. DOI: https://doi.org/10.1152/ physrev.2000.80.3.1107

Yair R, Shahar R, Uni Z. Prenatal nutritional manipulation by in ovo enrichment influences bone structure,composition, and mechanical properties. J Anim Sci 2013; 91(6):2784-2793. DOI: https://doi.org/10.2527/jas.2012-5548 